9 Thilo EH, Park-Moore B, Berman ER, Carson BS. Oxygen saturation by pulse oximetry in healthy infants at an altitude of $1610 \mathrm{~m}(5280 \mathrm{ft}) . A m \mathcal{F}$ Dis Child 1991:145:1137-40.

10 Swischuk LE. Emergency radiology of acutely ill or injured child. 2nd ed. Baltimore: Williams and Wilkins, 1986

11 Sackett DL, Haynes RB, Guyatt GH, Tugwell P. Clinical epidemiology: a basic science for clinical medicine. 2nd ed. Boston: Little, Brown, 1991:81-99.

12 Hosmer DW, Lemeshow S. Applied logistic regression. New York: John Wiley, 1989:10.

13 Norusis MJ. SPSSPC+ advanced statistics. Chicago, Illinois: SPSS, 1990 B47-61.

14 Mulholland EK, Olinsky A, Shann FA. Clinical findings and severity of acute bronchiolitis. Lancet 1990;335:1259-61.

15 Hall CB, Hall WJ, Speers DM. Clinical and physiological manifestations of bronchiolitis and pneumonia, outcome of respiratory syncytial virus. $\mathrm{Am} \mathcal{f}$ Dis Child 1979;133:798-802.

16 Shaw KN, Bell LM, Sherman NH. Outpatient assessment of infants with bronchiolitis. Am $\mathcal{F}$ Dis Child 1991;145:151-5.

17 Rosen LM, Yamamoto LG, Wiebe RA. Pulse oximetry to identify a high-risk group of children with wheezing. Am I Emerg Med 1989;7:567-70.

18 Berman S, Shanks MB, Feiten D, Horgan JG, Rumack C. Acute respiratory infections during the first three months of life: clinical, radiologic and physiologic predictors of etiology. Pediatr Emerg Care 1990;6:179-82.

19 Green M, Brayer AF, Schenkman KA, Wald ER. Duration of hospitalization in previously well infants with respiratory syncytial virus infection. Pediatr Infect Dis f 1989;8:601-5.

20 Farr BM, Sloman AJ, Fisch MJ. Predicting death in patients hospitalized for community-acquired pneumonia. Ann Intern Med 1991;115:428-36.

21 British Thoracic Society Research Committee. Community-acquired pneumonia in adults in British hospitals in 1982-1983: a survey of aetiology, mortality, prognostic factors and outcome. $Q \mathcal{f}$ Med 1987;239:195-220.

22 Banks RA, George RC, McNicol MW. Pneumococcal pneumonia with bacteraemia. Br $\mathcal{F}$ Dis Chest 1984;78:352-7.

23 Ransohoff DF, Feinstein AR. Problems of spectrum and bias in evaluating the efficacy of diagnostic tests. $N$ Engl I Med 1978;299:926-30.

24 Reynolds EOR. The effect of breathing 40 percent oxygen in the arterial blood gas tensions of babies with bronchitis. $\mathcal{F}$ Pediatr 1963;63:1135-9.

25 Hook EW III, Horton CA, Schaberg DR. Failure of intensive care unit to influence mortality from pneumococcal bacteremia. $\Im A M A$ 1983;249: 1055-7.

(Accepted 9 December 1992)
Imperial Cancer Research

Fund, Cancer

Epidemiology Unit, Gibson

Building, Radcliffe

Infirmary, Oxford

OX2 6HE

Eve Roman, staff scientist

Valerie Beral, director

Diana Bull, research officer

Krys Baker, research officer

Stoke Mandeville Hospital, Aylesbury,

Buckinghamshire

HP21 8AL

Ann Watson, consultant

haematologist

Royal Berkshire Hospital, Reading, Berkshire RG1 5AN

Sandra Buckle, study coordinator

Hilary Ryder, Malcolm

Sargent social worker

Carol Barton, consultant

haematologist

Correspondence to:

Dr Roman.

BMF 1993;306:615-21

\title{
Case-control study of leukaemia and non-Hodgkin's lymphoma among children aged 0-4 years living in West Berkshire and North Hampshire health districts
}

\author{
Eve Roman, Ann Watson, Valerie Beral, Sandra Buckle, Diana Bull, Krys Baker, Hilary Ryder, \\ Carol Barton
}

Abstract

Objective-To investigate the relation between parental employment in the nuclear industry and childhood leukaemia and non-Hodgkin's lymphoma.

Design-Case-control study.

Setting-West Berkshire and Basingstoke and North Hampshire District Health Authorities.

Subjects-54 children aged 0-4 years who had leukaemia or non-Hodgkin's lymphoma diagnosed during 1972-89, who were born in the study area and were resident there when cancer was diagnosed. Six controls were selected for each case: four from hospital delivery registers and two from livebirth registers maintained by the NHS central register. Controls were matched for sex, date of birth (within six months), and area of residence at birth and time of diagnosis.

Main outcome measures-Parents' employment by the nuclear industry and exposure to ionising radiation at work.

Results-Five $(9 \%)$ of the 54 cases and $14(4 \%)$ of the 324 controls had fathers or mothers, or both, who had been employed by the nuclear industry (relative risk $2 \cdot 2,95 \%$ confidence interval $0 \cdot 6$ to $6 \cdot 9$ ). Nuclear industry employees who work in areas where exposure to radiation is possible are given film badges to monitor their exposure to external penetrating ionising radiation. Three fathers of cases and two fathers of controls (and no mothers of either) had been monitored in this way before their child was conceived (relative risk $9 \cdot 0,95 \%$ confidence interval 1.0 to $107 \cdot 8$ ). No father (of a case or control) had accumulated a recorded dose of more than $5 \mathrm{mSv}$ before his child was conceived, and no father had been monitored at any time in the four years before his child was conceived. A dose-response relation was not evident among fathers who had been monitored.

Conclusions-These results suggest that the children of fathers who had been monitored for exposure to external penetrating ionising radiation in the nuclear industry may be at increased risk of developing leukaemia before their fifth birthday. The finding is based on small numbers and could be due to chance. If the relationship is real the mechanisms are far from clear, except that the effect is unlikely to be due to external radiation; the possibility that it could be due to internal contamination by radioactive substances or some other exposure at work should be pursued. The above average rates of leukaemia in the study area cannot be accounted for by these findings.

\section{Introduction}

We previously found an increased incidence of childhood leukaemia in the West Berkshire and Basingstoke and North Hampshire District Health Authorities during 1972-85. ${ }^{1}$ The excess was concentrated in children under 5 years who were living within $10 \mathrm{~km}$ of the atomic weapons establishments at Aldermaston and Burghfield. We report here the results of a case-control study set up to investigate whether the excess was related to parents' employment in the nuclear industry.

\section{Subjects and methods}

The study was carried out in the West Berkshire and the Basingstoke and North Hampshire District Health Authorities. Information about children under 5 years old living in the study area who had leukaemia or nonHodgkin's lymphoma diagnosed between 1972 and 1989 was ascertained from multiple sources. Children with non-Hodgkin's lymphoma were included because of the current understanding, based on immunological studies, that acute lymphoblastic leukaemia and nonHodgkin's lymphoma represent opposite ends of the same spectrum of disease. ${ }^{23}$ Most cases were notified by consultants at the Royal Berkshire District Hospital, the Basingstoke District Hospital, and hospitals in the surrounding districts. General practitioners within the study area also provided details of children with cancer. In addition, listings of children with leukaemia or non-Hodgkin's lymphoma were obtained from the childhood cancer research group's national registry of childhood tumours. ${ }^{4}$ All diagnoses were histologically confirmed.

We studied only children who were born and had cancer diagnosed in the study area. The mothers of 56 of the 71 children diagnosed during 1972-89 were living in the study area at the time of their child's birth. Two of these 56 children are not included in the analyses; both died in the early 1970s shortly after 
having non-Hodgkin's lymphoma diagnosed, and we were unable to verify their parents' names or dates of birth.

Six control children were selected for each case: two from birth registers maintained by the NHS central register and four from delivery registers in the two district hospitals in the study area.

The two birth registry controls were chosen by staff employed at the central register in Southport. The entry for the case was located in the birth register and the first preceding and the first succeeding entries were selected who matched the case with respect to sex, date of birth (plus or minus six months), district of birth registration, and family health services authority of the child's first general practitioner. Controls were further matched with cases for residence in the study area at time of diagnosis. Control children who were found to have died or to have moved out of the study area before their matched case had cancer diagnosed were replaced.

Mother's address is not recorded in the birth registers maintained by the central register. To allow matching for proximity of mother's residence to a nuclear establishment at the time of her child's birth a further series of controls was selected from locally held hospital delivery registers. Mother's address as recorded in the delivery register was used to assign births to $5 \mathrm{~km}$ bands round the nuclear establishments in the study area, and controls were chosen from the same $5 \mathrm{~km}$ band as their associated case. These $5 \mathrm{~km}$ bands correspond to the boundaries used in our previous analyses.' Selecting controls from delivery registers also enabled matching for mother's age (plus or minus five years), child's sex and date of birth (plus or minus six months), district health authority of birth, and residence in the study area at the time of diagnosis. Controls selected from the delivery register were chosen by locating the birth entry of the case and selecting the two closest preceding and the two closest succeeding entries fulfilling the matching criteria. For the 10 case children who were not born in maternity units within the study area (eight were born at home and two in hospitals in adjacent health authorities) the place in the register where the birth would have been entered was located and controls were chosen as above.

Children were considered ineligible to be controls if they were a twin, were adopted, or had a serious congenital defect. Controls whose mother had died (two) or was unavailable because of ill health (one) and controls whose father could not be identified (eight) were also considered ineligible. As control families were traced through their general practitioner with the facilities offered by the central register, families who emigrated before the study began (five) and those whose current family health services authority was not recorded (five) or incorrectly recorded (11) were replaced by the next eligible control in the series. One control was selected from both the delivery register and birth register. This child was assigned to the delivery register series and another control was chosen from the birth register.

\section{DATA COLLECTION}

Information about case and control children and their parents was obtained from four sources: the child's birth certificate, personal interview of parents, mother's obstetric notes, and employment and health physics records held by the nuclear industry (table I).

Birth certificates of cases and controls were obtained from the Office of Population Censuses and Surveys. Mother's and father's names, mother's address, and father's occupation are routinely recorded on the birth certificate. This information was used to confirm residential details and parental names. Father's occupation and social class were coded by the Office of
Population Censuses and Surveys 1980 classification scheme. ${ }^{5}$ Father's occupation was assigned to one of eight groups on the basis of knowledge of the industries in the area and of previous reports of association between parental occupation and childhood cancer. ${ }^{6-8}$

Parents of cases and controls were interviewed by a trained nurse interviewer using a structured questionnaire. Separate questionnaires were used for mothers and fathers. A full residential and occupational history ${ }_{x}$ including specific questions about employment at nuclear establishments, was recorded for each parent. To improve the quality of information obtained at interview, a form asking parents to list the places in which they had lived and the jobs they had had was sent out in advance of the interview. Parent's social class and occupation was coded in the same way as the information on birth certificates. During the interview, mothers and fathers were also asked to confirm their own names and dates of birth and about their own health and habits. Additional questions about pregnancies, the index child, and other children in the family were incorporated in the mother's questionnaire. Because of the seriousness of the disease, interviewers knew whether they were approaching the parents of a case or control child.

The parents of three case children did not wish to be interviewed, and interviews with the corresponding controls of these children were not arranged. All mothers of the remaining 51 case children were interviewed but two fathers were not (table I). Of the parents of the 306 matched controls for these 51 cases, $223(73 \%)$ mothers and $219(72 \%)$ fathers were interviewed. Among the 83 controls for whom neither parent was interviewed, 58 sets of parents declined an interview, 14 were not approached on the advice of their general practitioner, and the current addresses of the remaining 11 were not traced. For each of the 51 case children whose mother was interviewed ${ }^{\circ}$ at least one mother of a corresponding control was also interviewed: the numbers of cases having one, two, three, four, five, and six corresponding interviewed control mothers were one, three, three, 21, 15, and eight respectively. For the 49 case children whose father was interviewed the numbers of cases having one, two, three, four, five, and six corresponding interviewed control fathers were one, three, five, 18, 15 , and seven respectively.

We located the obstetric notes of 37 of the $42(88 \%)$ mothers of case children born at the Royal Berkshire District Hospital or the Basingstoke District Hospital. The obstetric notes of 196 of the $222(88 \%)$ controls associated with these 37 cases were also obtained (table I). Information about the pregnancy and delivery and about the name and date of birth of the father (where recorded) were abstracted from the obstetric notes. Obstetric data were abstracted for at

TABLE I-Information obtained about parents of cases and controls

\begin{tabular}{|c|c|c|}
\hline Information & $\begin{array}{c}\text { No }(\%) \text { of } \\
\text { cases } \\
(n=54)\end{array}$ & $\begin{array}{l}\text { No }(\%) \text { of } \\
\text { controls* } \\
(n=324)\end{array}$ \\
\hline \multicolumn{3}{|l|}{ Name: } \\
\hline Mother & $54(100)$ & $324(100)$ \\
\hline Father & $53(98)$ & $324(100)$ \\
\hline \multicolumn{3}{|l|}{ Date of birth: } \\
\hline Mother & $54(100)$ & $312(96)$ \\
\hline Father & $52(96)$ & $290(90)$ \\
\hline Father's occupation recorded on birth certificate & $52(96)$ & $323(99)$ \\
\hline \multicolumn{3}{|l|}{ Completed questionnaire: } \\
\hline Mother & $51(94)$ & $223(73) t$ \\
\hline Father & 49 (91) & $219(72) \dagger$ \\
\hline Obstetric notes abstracted $\ddagger$ & $37(88)$ & $196(88)$ \\
\hline
\end{tabular}

* $\mathrm{Six}$ controls were sought for each case.

†Mothers and fathers of three case children were not interviewed and HMothers and fathers of three case children were not intery
interviews were not sought for their 18 corresponding controls.

interviews were not sought for their 18 corresponding controls. fObstetric notes were sought for only the 42 cases born at Royal Berkshire
District Hospital or Basingstoke District Hospital and their 222 corresDonding controls. 
TABLE II-Characteristics of children who had leukaemia or non-Hodgkin's lymphoma diagnosed before their fifth birthday in the West Berkshire and Basingstoke and North Hampshire District Health Authorities during 1972-89 and were born to mothers resident in the area

\begin{tabular}{|c|c|c|c|c|}
\hline & $\begin{array}{c}\text { Acute } \\
\text { lymphoblastic leukaemia }\end{array}$ & $\begin{array}{c}\text { Other } \\
\text { leukaemias }\end{array}$ & $\begin{array}{l}\text { Non-Hodgkin's } \\
\text { lymphoma }\end{array}$ & Total \\
\hline No of children diagnosed & 39 & 11 & 6 & 56 \\
\hline No included in the analysis & 39 & 11 & $4 \dagger$ & 54 \\
\hline \multicolumn{5}{|l|}{ Sex: } \\
\hline Male & 21 & 4 & 2 & 27 \\
\hline Female & 18 & 7 & 2 & 27 \\
\hline \multicolumn{5}{|l|}{ Age at diagnosis (years): } \\
\hline$\leqslant 1$ & 4 & 3 & 1 & 8 \\
\hline 2 & 11 & 4 & 1 & 16 \\
\hline 3 & 13 & 2 & 1 & 16 \\
\hline 4 & 11 & 2 & 1 & 14 \\
\hline \multicolumn{5}{|l|}{ Year of diagnosis: } \\
\hline $1972-4$ & 8 & 4 & 1 & 13 \\
\hline $1975-7$ & 9 & & 1 & 10 \\
\hline $1978-80$ & 9 & 3 & & 12 \\
\hline $1981-3$ & 6 & 1 & & 7 \\
\hline $1984-6$ & 1 & 2 & 1 & 4 \\
\hline $1987-9$ & 6 & 1 & 1 & 8 \\
\hline \multicolumn{5}{|l|}{ Year of birth: } \\
\hline$\leqslant 1970$ & 6 & 3 & 1 & 10 \\
\hline $1971-3$ & 10 & & 1 & 11 \\
\hline $1974-6$ & 8 & 3 & & 11 \\
\hline $1977-9$ & 3 & 2 & & 5 \\
\hline $1980-2$ & 5 & 2 & 1 & 8 \\
\hline$\geqslant 1983$ & 7 & 1 & 1 & 9 \\
\hline
\end{tabular}

*Includes seven children with acute myeloid leukaemia, two with chronic granulocytic leukaemia, and two with undifferentiated leukaemia. Two of the children with acute myeloid leukaemia and both of the children with undifferentiated leukaemia had Down's syndrome.

tTwo children are not included in the analyses. Both died in the early 1970 s, shortly after diagnosis. Only the child's name and diagnosis was known; parents' names and dates of birth were not verified and neither parent was traced.

TABLE III-Characteristics of the parents of cases and matched controls obtained from hospital delivery register and NHS birth register

\begin{tabular}{|c|c|c|c|c|}
\hline \multirow[b]{2}{*}{ Parental characteristic at time of child's birth } & \multirow{2}{*}{$\begin{array}{c}\text { No }(\%) \\
\text { of } \\
\text { cases }\end{array}$} & \multicolumn{3}{|c|}{ No $(\%)$ of controls } \\
\hline & & $\begin{array}{l}\text { Delivery } \\
\text { register }\end{array}$ & $\begin{array}{l}\text { Birth } \\
\text { register }\end{array}$ & Total \\
\hline \multirow{2}{*}{\multicolumn{5}{|c|}{ Mother's age (years) ${ }^{\star}$ : }} \\
\hline & & & & \\
\hline$\leqslant 24$ & $20(37)$ & 93 & 32 & $125(39)$ \\
\hline $25-29$ & $24(44)$ & 84 & 44 & $128(40)$ \\
\hline$\geqslant 30$ & $10(19)$ & 39 & 28 & $67(21)$ \\
\hline Not known & & & 4 & $4(1)$ \\
\hline \multicolumn{5}{|l|}{ Father's age (years): } \\
\hline$\leqslant 24$ & $10(19)$ & 44 & 17 & $61(19)$ \\
\hline $25-29$ & $26(48)$ & 73 & 36 & $109(34)$ \\
\hline$\geqslant 30$ & $16(30)$ & 77 & 45 & $122(38)$ \\
\hline Not known & $2(4)$ & 22 & 10 & $32(10)$ \\
\hline \multicolumn{5}{|c|}{ Distance of mother's residence from a nuclear establishment $(\mathrm{km})^{\star}$ : } \\
\hline$\leqslant 5$ & $11(20)$ & 44 & 18 & $62(19)$ \\
\hline $6-10$ & $24(44)$ & 96 & 36 & $132(41)$ \\
\hline $11-15$ & $11(20)$ & 44 & 29 & $73(23)$ \\
\hline$\geqslant 15$ & $8(15)$ & 32 & 25 & $57(18)$ \\
\hline \multicolumn{5}{|l|}{ Social classt: } \\
\hline I & $4(7)$ & 18 & 10 & $28(9)$ \\
\hline II & $11(20)$ & 43 & 16 & 59 (18) \\
\hline III Non-manual & $9(17)$ & 33 & 18 & $51(16)$ \\
\hline III Manual & $20(37)$ & 79 & 43 & $122(38)$ \\
\hline IV & $5(9)$ & 25 & 13 & $38(12)$ \\
\hline $\mathrm{V}$ & $1(2)$ & 8 & 6 & $14(4)$ \\
\hline Armed forces & $1(2)$ & 3 & & 3 (1) \\
\hline Inadequately described & $3(6)$ & 7 & 2 & 9 (3) \\
\hline
\end{tabular}

${ }^{\star}$ Delivery register controls and cases were matched for these variables.

†Social class was assigned on the basis of father's occupation as stated on the birth certificate.

least one control for the 37 cases. The numbers of cases having one, two, three, four, five, and six controls with obstetric data were one, none, two, two, 11 , and 21 respectively.

Parents' names, including mothers' maiden names, and dates of birth were checked against the employment and health physics records of past and present employees held by the Atomic Weapons Establishment, the Atomic Energy Authority, and the National Registry of Radiation Workers. These records were primarily compiled for epidemiological studies of the health of nuclear industry workers. ${ }^{9-11}$ Parents' surname, forename(s), sex, and date of birth were linked to these databases by industry staff. Different spellings of names were also checked. Eight potentially matching people with the same or similar names but missing or incomplete dates of birth were eliminated as true matches after thorough cross checking. Details about dates of employment and health physics records were obtained for all parents confirmed as having been employed at a nuclear establishment before their child's cancer was diagnosed (or for controls, before the date of diagnosis of the corresponding case).

\section{ANLYSIS OF DATA}

Data were entered on to a microcomputer with the database management system FOXPRO, ${ }^{12}$ and tabulations were produced with the statistical program SPSS. ${ }^{13}$ Relative risks were estimated as matched odds ratios by conditional maximum likelihood methods. ${ }^{14}$ Information on exposure was considered up until the time of diagnosis for cases and until the date of diagnosis of the corresponding case for controls. Confidence intervals and $\mathrm{p}$ values for relative risks were calculated by conditional exact methods based on the binomial distribution with the computer package EGRET. ${ }^{15}$ Two sided $\mathrm{p}$ values (given to two significant figures) and $95 \%$ confidence intervals are presented throughout.

\section{Results}

Table II gives the characteristics of children who had leukaemia or non-Hodgkin's lymphoma diagnosed during 1972-89 and who were born in the study area and resident there when their cancer was diagnosed. Fifty children had leukaemia diagnosed ( 39 had acute lymphoblastic leukaemia and 11 other forms of leukaemia) and six had non-Hodgkin's lymphoma. Of the 11 children with other forms of leukaemia, seven had acute myeloid leukaemia, two chronic granulocytic leukaemia, and two undifferentiated leukaemia. Two of the children with acute myeloid leukaemia, and both of the children with undifferentiated leukaemia, had Down's syndrome. The numbers of children diagnosed and born each year fluctuated, but the numbers were small and there was no noticeable trend with time.

At the time of their child's birth, the parents of case and control children were similar with respect to their age, distance of residence from a nuclear establishment, and social class (table III). As expected, the matching to cases was best for controls selected from delivery registers. In the analyses which follow relative risks were estimated by using data from all available controls. Analyses were also performed with birth register and delivery register controls separately. The findings were similar, although the number of controls per case was small.

\section{EMPLOYMENT BY NUCLEAR INDUSTRY}

Fathers of children with leukaemia or non-Hodgkin's lymphoma were more likely than fathers of control children to have been employed by the nuclear industry, but the excess was not significant. Linkage to nuclear industry databases identified four (out of 54) case fathers and 10 (out of 324) control fathers who were employed at some time before their child had cancer diagnosed (relative risk $2 \cdot 5, p=0 \cdot 25$; table IV). All four fathers of case children and nine of the 10 fathers of control children were employed by the industry before their child was conceived (relative risk $2 \cdot 8, \mathrm{p}=0 \cdot 20$ ).

Employees who work in areas where exposure to ionising radiation is possible are issued with personal film badges or other dosimeters to monitor their exposure. The risk of leukaemia or non-Hodgkin's lymphoma was significantly increased in children whose fathers had been thus monitored: four fathers of cases and three fathers of controls had been issued with monitoring devices before their child's illness was diagnosed (relative risk $8.0, p=0.02$ ), and of these, three fathers of cases and two fathers of controls were monitored before their child's conception (relative risk $9 \cdot 0, p=0 \cdot 047$ ).

The figure summarises information on timing of 
TABLE IV-Numbers of cases and controls and relative risks (95\% confidence intervals) for childhood leukaemia and non-Hodgkin's lymphoma by father's employment and monitoring for exposure to ionising radiation at nuclear establishment

\begin{tabular}{|c|c|c|c|c|c|}
\hline \multirow[b]{2}{*}{$\begin{array}{l}\text { Father's employment at a nuclear } \\
\text { establishment before child's diagnosis }\end{array}$} & \multirow[b]{2}{*}{$\begin{array}{c}\text { Cases } \\
(\mathrm{n}=54)\end{array}$} & \multicolumn{3}{|c|}{ Controls } & \multirow[b]{2}{*}{$\begin{array}{c}\text { Relative risk } \dagger \\
(95 \% \text { confidence interval })\end{array}$} \\
\hline & & $\begin{array}{c}\text { Delivery } \\
\text { register } \\
(n=216)\end{array}$ & $\begin{array}{c}\text { Birth } \\
\text { register } \\
(\mathrm{n}=108)\end{array}$ & $\begin{array}{c}\text { Total } \\
(n=324)\end{array}$ & \\
\hline Ever employed & 4 & 5 & 5 & 10 & $2.5(0.6$ to 9.0$)$ \\
\hline Before conception & 4 & 4 & 5 & 9 & $2.8(0.6$ to 10.5$)$ \\
\hline Conception to diagnosis & 1 & 2 & 3 & 5 & $1.2(0.1$ to 10.7$)$ \\
\hline Ever monitored for ionising radiation & 4 & 1 & 2 & 3 & $8 \cdot 0(1.4$ to $54 \cdot 6)$ \\
\hline Before conception & 3 & 1 & 1 & 2 & $9.0(1.0$ to 107.8$)$ \\
\hline Conception to diagnosis & 1 & & 1 & 1 & $6.0(0.1$ to $471 \cdot 0)$ \\
\hline
\end{tabular}

*Based on search of nuclear industry databases.

†Estimated by using informative matched sets.

TABLE v-Number of cases and controls and relative risks (95\% confidence intervals) for leukaemia and non-Hodgkin's lymphoma in children by mother's employment at a nuclear establishment

\begin{tabular}{lccccc}
\hline & & \multicolumn{4}{c}{ Controls } \\
\cline { 3 - 5 } $\begin{array}{l}\text { Mother's employment at a nuclear } \\
\text { establishment before child's diagnosis }\end{array}$ & $\begin{array}{c}\text { Cases } \\
(\mathrm{n}=54)\end{array}$ & $\begin{array}{c}\text { Delivery } \\
\text { register } \\
(\mathrm{n}=216)\end{array}$ & $\begin{array}{c}\text { Birth } \\
\text { register } \\
(\mathrm{n}=108)\end{array}$ & $\begin{array}{c}\text { Total } \\
(\mathrm{n}=324)\end{array}$ & $\begin{array}{c}\text { Relative riskt } \\
(95 \% \text { confidence interval })\end{array}$ \\
\hline $\begin{array}{l}\text { Ever employed } \\
\text { Before conception }\end{array}$ & 1 & 4 & 3 & 7 & $0 \cdot 9(0 \cdot 2$ to $7 \cdot 2)$ \\
Conception to birth & 0 & 4 & 2 & 6 & $0 \cdot 0(0 \cdot 0$ to $5 \cdot 1)$ \\
Birth to diagnosis & 1 & 1 & 1 & 2 & $3 \cdot 0(0 \cdot 1$ to $57 \cdot 6)$ \\
& 0 & 0 & 0 & 0 & $0 \cdot 0$
\end{tabular}

*Based on search of nuclear industry.

†Estimated by using informative matched sets.

$\ddagger$ No mothers had a record of monitoring for exposure to ionising radiation.

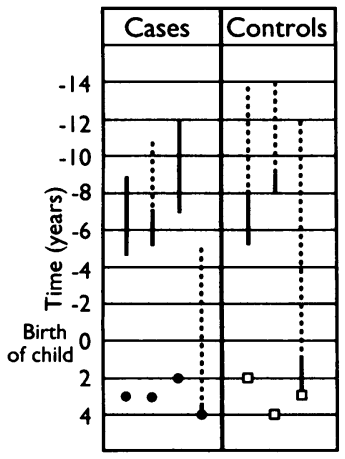

Employment details of the seven fathers identified from nuclear industry databases as having been monitored for exposure to ionising radiation.

Employed and monitored for

external radiation,....

employed and not monitored for external radiation, $\bullet$ indicates the age of child when leukaemia was diagnosed, $\square$ indicates the age of child when leukaemia was diagnosed in the matched case
The malignancies in children whose fathers were monitored for exposure to ionising radiation were not unusual. All four children had acute lymphoblastic leukaemia diagnosed between the ages of 2 and 4 years, the year of diagnosis ranging from 1972 to 1988 . None of the 11 children who had other forms of leukaemia and none of the four who had non-Hodgkin's lymphoma had fathers with a record of employment at a nuclear establishment.

We found no association with mother's employment in the nuclear industry. One mother of a case and seven mothers of controls were employed by the nuclear industry before their child's diagnosis (relative risk $0.9, p=1 \cdot 0)$. No mother of a case had worked at a nuclear establishment before her child's conception, and no mother had a record of being monitored for exposure to ionising radiation at any time before diagnosis (table $\mathrm{V}$ ).

In our study of the incidence of childhood leukaemia during 1972-85 the excess was concentrated in the 50 electoral wards in which half or more of the area was within $10 \mathrm{~km}$ of the atomic weapons establishments at Aldermaston and Burghfield.' All four case children whose fathers were monitored for exposure to ionising radiation were born within this $10 \mathrm{~km}$ circle. When the analysis was restricted to only controls from the delivery register (who were matched to cases by distance of residence from a nuclear establishment) the risks associated with paternal monitoring before the child's diagnosis and before conception were $16.0(95 \%$ confidence interval 1.6 to $788.0 ; p=0.013$ ) and 12.0 $(1.0$ to $630.0 ; p=0.054)$ respectively.

The questionnaire administered to parents included specific questions about work at nuclear establishments and monitoring for exposure to ionising radiation. All employees identified by linkage to industrial records also reported that they had worked in the nuclear industry and no additional parents reported having been an employee. Employees' reports of monitoring for exposure to ionising radiation agreed with the industrial records, except for one mother of a case who reported being monitored, but there was no record of this in the industry databases. Employees of outside contractors sometimes work on nuclear sites, and information about them is not held on nuclear industry's employee databases. Three additional parents reported that they worked on contract at nuclear sites and had been monitored for exposure to radiation before their child was diagnosed (one father of a case, after conception; one father of a control, before conception; one mother of a control, before conception). The risks estimated on the basis of information recorded at interview were consistent with those estimated on internal contamination by uranium in the year before his child had leukaemia diagnosed.

TABLE VI-Number of cases and controls and relative risks (95\% confidence intervals) for leukaemia and non-Hodgkin's lymphoma in children by father's occupation as recorded on the birth certificate and reported at interview

\begin{tabular}{|c|c|c|c|c|c|c|c|c|c|c|}
\hline \multirow[b]{3}{*}{ Exposure group $\dagger$} & \multicolumn{5}{|c|}{ Recorded on child's birth certificate } & \multicolumn{5}{|c|}{ Reported at interview ${ }^{\star}$} \\
\hline & \multirow[b]{2}{*}{ Cases } & \multicolumn{3}{|c|}{ Controls } & \multirow{2}{*}{$\begin{array}{c}\text { Relative risk } \neq \\
(95 \% \\
\text { confidence interval) }\end{array}$} & \multirow[b]{2}{*}{ Cases } & \multicolumn{3}{|c|}{ Controls } & \multirow{2}{*}{$\begin{array}{c}\text { Relative riskł } \\
(95 \% \\
\text { confidence interval })\end{array}$} \\
\hline & & $\begin{array}{l}\text { Delivery } \\
\text { register }\end{array}$ & $\begin{array}{c}\text { Birth } \\
\text { register }\end{array}$ & Total & & & $\begin{array}{l}\text { Delivery } \\
\text { register }\end{array}$ & $\begin{array}{l}\text { Birth } \\
\text { register }\end{array}$ & Total & \\
\hline Agriculture & 2 & 9 & 2 & 11 & $1 \cdot 1(0.1$ to 5.9$)$ & 3 & 10 & 5 & 15 & $0.8(0.1$ to 3.3$)$ \\
\hline Building and construction & 5 & 25 & 14 & 39 & $0.8(0.2$ to 2.0$)$ & 11 & 20 & 9 & 29 & $1.8(0.8$ to 4.2$)$ \\
\hline Drivers and related & 3 & 24 & 6 & 30 & $0.6(0.1$ to 2.0$)$ & 7 & 20 & 4 & 24 & $1.3(0.4$ to 3.2$)$ \\
\hline Electrical and electronic & 8 & 14 & 8 & 22 & $2.5(0.9$ to 6.8$)$ & 9 & 13 & 8 & 21 & $2.2(0.8$ to 5.9$)$ \\
\hline Engineering and metal & 8 & 25 & 20 & 45 & $1.1(0.4$ to 2.5$)$ & 12 & 22 & 15 & 37 & $1.5(0.6$ to 3.2$)$ \\
\hline Medical and laboratory & 0 & 7 & 2 & 9 & $0.0(0.0$ to 3.0$)$ & 2 & 8 & 3 & 11 & $0.9(0.1$ to 4.0$)$ \\
\hline Wood & 1 & 8 & 2 & 10 & $0.6(0.0$ to 4.2$)$ & 3 & 7 & 3 & 10 & $1 \cdot 4([0 \cdot 2$ to $5 \cdot 5)$ \\
\hline Other occupations & 25 & 95 & 50 & 145 & $1.1(0.6$ to 2.0$)$ & 13 & 60 & 29 & 89 & $0.5(0.2$ to 1.0$)$ \\
\hline Total & $52 \S$ & 207 & 104 & 311 & & 49 & 143 & 68 & $211 \|$ & \\
\hline
\end{tabular}

*Father's occupation in the three years before birth up until diagnosis. Only periods of employment of at least three months are included.

+Codes from the Office of Population Censuses and Surveys classification of occupations': agriculture 107, 166-70, 172; building and construction 18, 68, $82-4,88-9,92-4,300-16,330$; drivers and related 52, 95, 100, 124, 127-8, 141, 161, 317-29, 331-2, 336, 338; electrical and electronic 12, 62, 71-2, 86-7, 121-2, 252-9, 273-4, 276, 283, 286; engineering and metal 69-70, 74-7, 81, 91, 231-51, 260-72, 275, 277, 285, 343-4; medical and laboratory 41-51, 61, 65-6, 73, 80, $153,155-6,220,288$; wood $203,213-9,224,293$

$\ddagger$ Estimated using informative matched sets.

fEstimated using informative matched sets.

Eight interviewed control fathers are excluded because their corresponding case fathers were not interviewed. 


\begin{tabular}{|c|c|c|c|c|c|c|c|c|c|c|}
\hline \multirow[b]{3}{*}{$\begin{array}{l}\text { Suspected risk factor in } \\
\text { index child/pregnancy }\end{array}$} & \multicolumn{5}{|c|}{ Obstetric records } & \multicolumn{5}{|c|}{ Reported at interview } \\
\hline & \multirow[b]{2}{*}{ Cases } & \multicolumn{3}{|c|}{ Controls } & \multirow{2}{*}{$\begin{array}{c}\text { Relative risk } \\
(95 \% \\
\text { confidence interval) }\end{array}$} & \multirow[b]{2}{*}{ Cases } & \multicolumn{3}{|c|}{ Controls } & \multirow{2}{*}{$\begin{array}{c}\text { Relative risk }{ }^{\star} \\
(95 \% \\
\text { confidence interval })\end{array}$} \\
\hline & & $\begin{array}{l}\text { Delivery } \\
\text { register }\end{array}$ & $\begin{array}{l}\text { Birth } \\
\text { register }\end{array}$ & Total & & & $\begin{array}{l}\text { Delivery } \\
\text { register }\end{array}$ & $\begin{array}{l}\text { Birth } \\
\text { register }\end{array}$ & Total & \\
\hline Total & 37 & 139 & 57 & 196 & & 51 & 150 & 73 & 223 & \\
\hline Abdominal $x$ rays & 5 & 19 & 5 & 24 & $1.1(0.3$ to 3.7$)$ & 10 & 22 & 1 & 23 & $2.2(0.8$ to 5.6$)$ \\
\hline Ultrasound scans & 13 & 44 & 25 & 69 & $1 \cdot 1(0.4$ to 3.1$)$ & 22 & 68 & 30 & 98 & $1.2(0.5$ to 3.0$)$ \\
\hline Smoking & 8 & 28 & 12 & 40 & $0.9(0.3$ to 2.5$)$ & 9 & 42 & 18 & 60 & $0.5(0.2$ to 1.2$)$ \\
\hline Drinking alcohol & 3 & 8 & 2 & 10 & $1.8(0.3$ to 8.8$)$ & 29 & 96 & 30 & 126 & $1 \cdot 1(0.6$ to 2.2$)$ \\
\hline Birthweight $\geqslant 3500 \mathrm{~g}$ & 9 & 47 & 20 & 67 & $0.6(0.2$ to 1.4$)$ & 16 & 41 & 28 & 69 & $1.0(0.5$ to 2.1$)$ \\
\hline Gestational age $\geqslant 41$ weeks & 9 & 36 & 13 & 49 & $0.9(0.3$ to 2.3$)$ & 13 & 45 & 16 & 61 & $0.9(0.4$ to 1.9$)$ \\
\hline Caesarian delivery & 4 & 12 & 5 & 17 & $1.3(0.3$ to 4.2$)$ & 5 & 14 & 5 & 19 & $1.2(0.3$ to 3.4$)$ \\
\hline First pregnancy & 20 & 55 & 14 & 69 & $2.3(1.0$ to 5.3$)$ & 28 & 64 & 16 & 80 & $2.3(1.2$ to 4.9$)$ \\
\hline First livebirth & 22 & 71 & 17 & 88 & $1.8(0.8$ to 4.2$)$ & 30 & 75 & 21 & 96 & $2.0(1.0$ to 4.1$)$ \\
\hline
\end{tabular}

^Estimated by using informative matched sets.

the basis of information obtained from the nuclear industry.

\section{OTHER RISK FACTORS}

Table VI compares the occupations of fathers of cases and controls who were assigned to one of seven occupational groups where potentially hazardous exposures might have occurred. The information recorded on the birth certificate refers to one point in time-when the child's birth was registered-whereas the information reported at interview refers to a period of employment of three months or longer, at any time from three years before the child's birth up until diagnosis. Hence, fathers are counted once only in the birth certificate analysis, but may appear more than once in the interview analysis. For the two sets of analyses the findings are similar, but the data overlap. None of the fathers' job descriptions given on the birth certificate referred to work at a nuclear establishment. Mother's occupation is not routinely recorded on the birth certificate. No notable associations between paternal or maternal occupation and leukaemia or nonHodgkin's lymphoma in their children were evident from the birth certificate data or that collected at interview.

Information on possible risk factors for leukaemia and non-Hodgkin's lymphoma reported at interview and recorded in the obstetric notes are summarised in table VII. Of the 37 cases and 196 controls for whom obstetric notes were retrieved, $34(92 \%)$ cases and $140(71 \%)$ controls were interviewed and are included in both analyses. The relative risks estimated on the basis of data collected at interview and on the basis of data from obstetric notes are generally similar. The only significant association was an increased risk of leukaemia and non-Hodgkin's lymphoma associated with first pregnancy. No differences were detected between case and control parents with respect to their own health or the numbers of diagnostic radiographs they reported before their child was conceived, or habits such as swimming in local rivers or canals, or in the children's histories of being breast fed, their preschool activities, allergies, or viral infections.

\section{Discussion}

This study was set up to investigate whether the raised incidence of leukaemia in children aged 0-4 years in the West Berkshire and North Hampshire health districts, which was $60 \%$ above the national average in 1972-85, was related to parental employment in the nuclear industry. ${ }^{2}$ The fathers of four and the mother of one of the 54 children who were born in and had leukaemia or non-Hodgkin's lymphoma diagnosed in the study area had been employed in the nuclear industry before their child was diagnosed (relative risk $2 \cdot 2,95 \%$ confidence interval 0.6 to $6 \cdot 9$ ). This excess was not significant and was insufficient to account for the increased rates of leukaemia in the area.

After this study began, Gardner and colleagues reported the results of their case-control study of childhood leukaemia and non-Hodgkin's lymphoma around the Sellafield reprocessing plant. ${ }^{16}$ They found that children of men who had been exposed to external penetrating ionising radiation before their child was conceived were at an increased risk of leukaemia. Our results can be interpreted as supporting Gardner and colleagues' finding in that the fathers of three (out of 54) cases and two (out of 324) controls had been monitored for exposure to ionising radiation before their child was conceived (relative risk 9.0, 1.0 to $107 \cdot 8$ ).

\section{VALIDITY OF DATA BIAS AND CHANCE}

Although our result for paternal preconceptual exposure could be affected substantially by the play of chance because of small numbers, they are unlikely to be biased. Cases were ascertained from multiple sources, and it is doubtful that any were missed, although we cannot be certain. The exclusion of two children with non-Hodgkin's lymphoma (whose parents could not be traced) probably did not affect the results.

Information about parental employment and monitoring for exposure to ionising radiation was obtained from nuclear industry files and is likely to be complete and unbiased. The names and dates of birth of all parents of case and control children (regardless of whether or not they were interviewed) were cross checked against three databases of employees held by the nuclear industry, the completeness and accuracy of which are known to be high.9-11 Employment and exposure records date from before the occurrence of leukaemia in the children, and the link to industry files was done by industry staff who did not know who were the parents of cases and who were the parents of controls. Not all parents were interviewed and self reported details on radiation exposure could be biased, so emphasis is given here to results obtained from industrial records.

The apparent excess of fathers monitored for radiation among children with leukaemia does not seem to be because the number of such fathers in the control group was unusually low by chance. On the basis of estimates of the size and composition of the nuclear workforces in the study area, national fertility rates, and local migration rates, we estimate that the expected numbers of control fathers who were employed and monitored for exposure to ionising radiation are in broad agreement with the numbers observed. Nevertheless, our results should be interpreted cautiously as they are based on only three monitored fathers and it is not possible to assess reliably how many of the three leukaemias, if any, were caused by paternal preconceptual exposure to some occupational factor. 


\section{CAUSE OF THE EFFECT}

If the association between paternal preconceptual exposure to radiation and childhood leukaemia we found is not a chance finding, the effect is unlikely to be due to paternal exposure to the forms of external penetrating ionising radiation measured by monitoring devices. A more plausible explanation is that exposure to external radiation is a marker of exposure to some other hazard, such as internal contamination by a radioactive substance or a chemical. ${ }^{161819}$ The external doses recorded for the fathers in our study are orders of magnitude lower than the external doses received by survivors of the atomic bombs at Hiroshima and Nagasaki, whose children are not at an increased risk of childhood leukaemia. ${ }^{20}$ No father (of a case or a control child) in this study had a recorded cumulative external exposure to penetrating radiation above $5 \mathrm{mSv}$ before his child was conceived, and such low doses could accumulate from background radiation in about five years. Important differences between the exposures of atomic bomb survivors and nuclear industry workers are that nuclear industry workers are more likely to be contaminated internally by the ingestion, inhalation, or other intake of radioactive substances; to be exposed to other types of external radiation such as neutrons; and to be exposed to chemicals at work. Film badges monitor exposure to external penetrating and sparsely ionising radiation but not internal or other forms of radiation, and the fact of being issued with a film badge to monitor external penetrating radiation could, for certain workers, be a marker of exposure to other forms of radiation.

Insufficient is known about the radiobiological effects of many types of radiation and radioactive substances to which workers may be exposed, other than external penetrating radiation. Certain workers have been monitored for internal contamination by radionuclides and exposure to other forms of radiation such as neutrons since the 1950 s, but this is not done routinely and monitoring methods can be unreliable.

\section{COMPARISON WITH OTHER STUDIES}

If being monitored for exposure to external penetrating radiation can be a marker of other exposures in the workplace, some of which might be hazardous, studies of the relation between men's exposure to external radiation and leukaemia in their children could yield apparently inconsistent results. Two other case-control studies have not found evidence of an increased risk of leukaemia in association with fathers' preconceptual exposure to external ionising radiation. This could be because exposure to the hazardous substance or substances did not occur in those populations or that being monitored for exposure to external radiation was not a marker of the relevant exposure. ${ }^{1921}$ The fact that Gardner et al found a dose-response relation between fathers' preconceptual external exposure to penetrating ionising radiation and childhood leukaemia and we did not could be because the cumulative dose was a marker of exposure to some hazardous substance or substances at Sellafield but not elsewhere.

Apart from the apparent relation with fathers' preconceptual exposure to ionising radiation, we found no other notable associations. The age and sex distribution of children who had acute lymphoblastic leukaemia diagnosed in the study area conformed to expected patterns, with slightly more boys and a peak age at diagnosis of 3 years; the excess of Down's syndrome in young children with non-lymphocytic forms of leukaemia is as would be expected. ${ }^{22}{ }^{23}$ The relation with pregnancy order is also compatible with the results of other studies, although its meaning is unclear. ${ }^{2426}$ Among the 50 children diagnosed with leukaemia, no suggestion of an unusual distribution of leukaemic subtypes was found, although diagnostic information in the form of chromosome studies and cell markers became available only in recent years. The malignancies of children whose fathers were monitored for exposure to ionising radiation did not seem to be atypical: all had acute lymphoblastic leukaemia, their ages at diagnosis were not unusual, and the time of their diagnosis was not concentrated in any particular period.

\section{CONCLUSIONS}

The findings from this study, taken together with those of Gardner et al, suggest that the children of certain men who are monitored for exposure to external ionising radiation in the nuclear industry might be at an increased risk of leukaemia. Because the numbers are small and the results could be due to chance, studies of larger numbers of children are needed. A study investigating the occurrence of all cancers, not only leukaemia, and the incidence of other illnesses and conditions that could have a genetic cause among children of workers in the nuclear industry is under way.

If the effects seen in our study are real, the underlying mechanisms are far from clear. Nevertheless, the hazardous exposure is unlikely to be monitored external penetrating ionising radiation. The possibility that the effects could be due to internal contamination by radioactive substances, a chemical, or some other exposure at work should be explored.

The Department of Health funded AW and SB and the data collection phase of this study. We thank the parents who participated in the study, the general practitioners and hospital staff who helped us, and Lynn Aston, Jim Donovan, Gerald Draper, and Charles Stiller who advised and supported us throughout. We also thank the health physicists who supplied data, particularly Jane Jeffries, Gerry Kendall, Dallas Law, and Len Salmon. Pat Ansell and Margo Pelerin helped with data collection; Eva Alberman, Martin Bobrow, Pat Doyle, Dudley Goodhead, Hazel Inskip, Richard Peto, and Peter Smith commented on earlier drafts; and Sarah Jones and Juliet Jain produced the manuscript. We would especially like to acknowledge Martin Gardner, who died on 22 January 1993, who had advised us on the conduct of the study and commented on the final report.

1 Roman E, Beral V, Carpenter L, Watson A, Barton C, Ryder $\mathrm{H}$, et al. Childhood leukaemia in the West Berkshire and Basingstoke and North Hampshire District Health Authorities in relation to nuclear establishments in the vicinity. BMf 1987;294:597-602.

2 Committee on Medical Aspects of Radiation in the Environment (COMARE). Third report. Report on the incidence of childhood cancer in the west Berkshire and north Hampshire area, in which are situated the Atomic Weapons Research and north Hampshire area, in which are situated the Atomic Weapons Research Establisment, Aldermasto

3 Committee on Medical Aspects of Radiation in the Environment (COMARE). Second report. Investigation of the possible increased incidence of leukaemia in young people near the Dounreay nuclear establishment, Caithness, Scotland. London: HMSO, 1988.

4 Stiller CA, O'Connor CM, Vincent TJ, Draper GJ. The national registry of childhood tumours and the leukaemia/lymphoma data for 1966-83. London: HMSO, 1991:7-16. (Studies on medical and population subjects No 53.)

5 Office of Population Censuses and Surveys. Classification of occupations and coding index. London: HMSO, 1980.

6 Sanders BM, White GC, Draper GJ. Occupations of fathers of children dying from neoplasms. I Epidemiol Community Health 1981;35:245-50.

7 O'Leary LM, Hicks AM, Peters JM, London S. Parental occupational exposures and risk of childhood cancer: a review. Am f Ind Med 1991;20: 17-35.

8 McKinney PA, Alexander FE, Cartwright RA, Parker L. Parental occupations of children with leukaemia in west Cumbria, north Humberside, and Gateshead. BMF 1991;302:681-7.

9 Beral V, Fraser P, Carpenter L, Booth M, Brown A, Rose G. Mortality of employees of the Atomic Weapons Establishment, 1951-82. BMF 1988;297: 757-70.

10 Fraser $\mathrm{P}$, Booth $\mathrm{M}$, Beral V, Inskip H, Firsht S, Speak S. Collection and validation of data in the United Kingdom Atomic Energy Authority mortality study. $B M \mathcal{F} 1985 ; 291: 435-9$.

11 Kendall GM, Muirhead CR, MacGibbon BH, O'Hagan JA, Conquest AJ, Goodhill AA, et al. Mortality and occupational exposure to radiation: first analysis of the National Registry for Radiation Workers. BMJ 1992;304: 220-5.

12 FOXPRO: user's guide. Perrysburg, Ohio: Fox Holdings, 1991.
13 SPSS. Statistical package for the social sciences-X: user's guide. New York: McGraw Hill, 1989 .

14 Breslow NE, Day NE. Statistical methods in cancer research. Vol 1. The analysis of case-control studies. Lyon: International Agency for Research on Cancer, 1980

15 EGRET: user's guide. Seattle: Statistics and Epidemiology Research Corporation, 1989 
16 Gardner MJ, Snee MP, Hall AJ, Powell CA, Downes S, Terrell JD. Results of case-control study of leukaemia and lymphoma among young people near Sellafield nuclear plant in West Cumbria. BMF 1990;300:423-9.

17 Gardner MJ. Paternal occupations of children with leukaemia. BMJ 1992;305: 715.

18 Beral V. Leukaemia and nuclear installations. $B M 7$ 1990;300:411-2.

19 McLaughlin JR, Anderson TW, Clarke EA, King W. Occupational exposure of fathers to ionizing radiation and the risk of leukaemia in offspring- a case-control study. Ottawa, Canada: Atomic Energy Control Board, 1992. (AECB project study. Ottawa,

20 Yoshimoto Y, Mabuchi K. Mortality and cancer risk among the offspring ( $\mathrm{Fi}$ ) of atomic bomb survivors. $\Im$ Radiat Res 1991;Suppl:294-300.

21 Urquhart JD, Black RJ, Muirhead MJ, Sharp L, Maxwell M, Eden OB, et al. Case-control study of leukaemia and non-Hodgkin's lymphoma in childre in Caithness near the Dounreay nuclear installation. BMJ 1991;302:687-92.

22 Doll R. The epidemiology of childhood leukaemia. Journal of Royal Statistical Society 1989;152:1-11.

23 Narod SA, Stiller C, Lenoir GM. An estimate of the heritable fraction of childhood cancer. Br f Cancer 1991;63:993-9.

24 Van Steensel-Mol HA, Valkenbuirg HA, Vandenbroucke JP, Van Zanen GE. Are maternal fertility problems related to childhood leukaemia? Int Epidemiol 1985:14:555-9.

25 Kaye SA, Robison LL, Smithson WA, Gunderson P, King FL, Neglia JP. Maternal reproductive history and birth characteristics in childhood acute leukaemia. Cancer 1991;68:1351-5.

26 Greaves MF. Speculations on the cause of childhood acute lymphoblastic leukaemia. Leukaemia 1988;2:120-5.

(Accepted l February 1993)

\section{Comparison of nifedipine and propranolol as second line agent for hypertension in black Kenyans}

\author{
N R Poulter, J E Sanderson, A V Thompson, * \\ P S Sever, C L Chang
}

Wellcome Trust Research Laboratories, PO Box 43640, Nairobi, Kenya N R Poulter, study coordinator

JE Sanderson, Wellcome lecturer in medicine A V Thompson, research associate

P S Sever, professor of clinical pharmacology and therapeutics C L Chang, research fellow

Correspondence to: Dr N R Poulter, Department of

Epidemiology and Public Health, University College London, London WC1E 6EA.

${ }^{\star}$ Dr Thompson has since died.

$B M 71993 ; 306: 621-2$
Nifedipine is reported to be particularly effective as an antihypertensive agent in low renin hypertension.' Because of the predominance of low renin hypertension among black Kenyan patients we compared the efficacy of propranolol plus diuretic, a standard treatment in Africa, ${ }^{2}$ with nifedipine plus diuretic in Kenyan patients whose blood pressure was not controlled by diuretic treatment.

\section{Patients, methods, and results}

Thirty seven black Kenyans aged 30-69 attending a hospital clinic for hypertension were admitted to this double blind crossover trial. All treatment was withdrawn for a minimum of two weeks, after which inclusion in the trial depended on a diastolic blood pressure $>105 \mathrm{~mm} \mathrm{Hg}$. This was followed by four weeks of treatment with a diuretic (hydrochlorothiazide $25 \mathrm{mg}$ once daily), when those whose diastolic blood pressure fell below $90 \mathrm{~mm} \mathrm{Hg}$ were withdrawn from the trial. Patients were then randomly allocated, in balanced blocks of four, to six weeks' treatment with either diuretic plus slow release nifedipine $20 \mathrm{mg}$ twice daily or diuretic plus propranolol $80 \mathrm{mg}$ twice daily. After another four weeks of treatment with diuretic alone the study treatments were crossed over.

Blood pressure was measured with a random zero sphygmomanometer by one of three observers whose technique had been standardised beforehand. At each visit blood pressure was recorded twice after five minutes' lying down, a radial pulse being measured between readings, and blood pressure and radial pulse were recorded after two minutes' standing. Patients were seen every two weeks throughout the trial. At the start of the trial and at the end of each stage patients were weighed and full biochemical blood screens, including plasma renin activity, were carried out. Plasma renin activity was estimated (after standardised sampling) by radioimmunoassay of angiotensin I generated by incubating plasma for four hours. Results were analysed with Student's $t$ test for paired data and Hills and Armitage's method for analysing data from crossover trials.

Five patients were withdrawn after responding to diuretic treatment alone. Another patient withdrew because of work commitments, and two were withdrawn while taking propranolol (one patient's diastolic blood pressure rose above $125 \mathrm{~mm} \mathrm{Hg}$ and one had symptoms suggesting heart failure). Of the 29 remaining patients, 16 initially took nifedipine plus diuretic. This combination produced significantly lower systolic and diastolic blood pressures than propranolol plus diuretic $(p<0.05)$ (table). Both combinations of drugs significantly reduced blood pressure compared with diuretic alone $(p<0.05)$.

There were no significant changes in the patients' mean weight and serum creatinine and sodium concentrations throughout the trial. Serum uric acid and blood urea concentrations rose and serum potassium fell significantly during diuretic treatment, suggesting good compliance (confirmed by pill counts and the changes in pulse rates). Plasma renin activity was low and changed with treatment (table). Twenty two patients' lying mean arterial blood pressure and 19 patients' standing mean arterial blood pressure fell more with nifedipine than with propranolol. Although those whose blood pressure fell more when nifedipine was added to diuretic had a lower mean plasma renin activity $(0.47(\mathrm{SD} 0.60) \mathrm{nmol} / / \mathrm{h})$, these differences were not significant ( $t$ test). One patient was withdrawn because of side effects (see above), but, otherwise, side effects were few. No patients complained of severe headaches or flushing while taking nifedipine.

\section{Comment}

Both diuretics and calcium antagonists are effective and superior to $\beta$ blockers in treating black hypertensive patients. ${ }^{4}$ We have previously shown diuretics plus nifedipine to be an effective combination for black

Mean (95\% confidence interval) lying and standing blood pressure and pulse rate and median (range) plasma renin activity in 29 patients at each stage of trial

\begin{tabular}{|c|c|c|c|c|c|c|c|}
\hline & \multicolumn{3}{|c|}{ Lying } & \multicolumn{3}{|c|}{ Standing } & \multirow{3}{*}{$\begin{array}{c}\text { Plasma } \\
\text { renin } \\
\text { activity } \\
(\mathrm{nmol} / \mathrm{h})\end{array}$} \\
\hline & \multicolumn{2}{|c|}{ Blood pressure ( $\mathrm{mm} \mathrm{Hg}$ ) } & \multirow{2}{*}{$\begin{array}{l}\text { Pulse rate } \\
\text { (beats } / \mathrm{min} \text { ) }\end{array}$} & \multicolumn{2}{|c|}{ Blood pressure $(\mathrm{mm} \mathrm{Hg})$} & \multirow{2}{*}{$\begin{array}{l}\text { Pulse rate } \\
\text { (beats/min) }\end{array}$} & \\
\hline & Systolic & Diastolic & & Systolic & Diastolic & & \\
\hline 1 Before treatment & $\begin{array}{c}180 \\
(169 \text { to } 191)\end{array}$ & $\begin{array}{c}114 \\
\text { (109 to } 119)\end{array}$ & $\begin{array}{c}70 \\
(66 \text { to } 74)\end{array}$ & $\begin{array}{c}175 \\
\text { (165 to } 184)\end{array}$ & $\begin{array}{c}122 \\
(116 \text { to } 127)\end{array}$ & $\begin{array}{c}79 \\
(74 \text { to } 83)\end{array}$ & $\begin{array}{c}0.02 \\
(0-1 \cdot 48)\end{array}$ \\
\hline 2 After diuretic alone & $\begin{array}{c}167 \\
\text { (156 to } 178)\end{array}$ & $\begin{array}{c}106 \\
\text { (101 to } 110)\end{array}$ & $\begin{array}{c}73 \\
\text { (69 to } 77)\end{array}$ & $\begin{array}{c}163 \\
\text { (154 to } 173 \text { ) }\end{array}$ & $\begin{array}{c}112 \\
\text { (107 to } 117 \text { ) }\end{array}$ & $\begin{array}{c}83 \\
\text { (78 to } 88)\end{array}$ & $\begin{array}{c}0.29 \\
(0-2 \cdot 65)\end{array}$ \\
\hline 3 After diuretic + propranolol & $\begin{array}{c}150 \\
\text { (140 to } 159)\end{array}$ & $\begin{array}{c}95 \\
\text { (91 to } 99 \text { ) }\end{array}$ & $\begin{array}{c}61 \\
\text { (57 to } 65)\end{array}$ & $\begin{array}{c}145 \\
\text { (135 to } 156)\end{array}$ & $\begin{array}{c}100 \\
\text { (96 to } 104)\end{array}$ & $\begin{array}{c}66 \\
\text { (61 to } 70)\end{array}$ & $\begin{array}{c}0 \cdot 23 \\
(0-6 \cdot 15)\end{array}$ \\
\hline 4 After diuretic + nifedipine & $\begin{array}{c}141 \\
(135 \text { to } 147)\end{array}$ & $\begin{array}{c}91 \\
(87 \text { to } 95)\end{array}$ & $\begin{array}{c}77 \\
\text { (72 to } 82)\end{array}$ & $\begin{array}{c}135 \\
\text { (129 to } 141)\end{array}$ & $\begin{array}{c}94 \\
(89 \text { to } 99)\end{array}$ & $\begin{array}{c}90 \\
\text { (84 to } 95)\end{array}$ & $\begin{array}{c}0.58 \\
(0-76 \cdot 9)\end{array}$ \\
\hline $\begin{array}{l}5 \text { Difference between } 3 \text { and } 4 \\
\text { averaged over periods }\end{array}$ & $\begin{array}{c}8 \cdot 2^{\star} \\
(0 \cdot 6 \text { to } 15 \cdot 8)\end{array}$ & $\begin{array}{c}4 \cdot 1^{\star} \\
(0 \cdot 2 \text { to } 8 \cdot 0)\end{array}$ & $\begin{array}{c}-15 \cdot 9 \star \star \\
(-20 \cdot 4 \text { to }-11 \cdot 4)\end{array}$ & $\begin{array}{c}9 \cdot 9^{\star} \\
(0.5 \text { to } 19 \cdot 3)\end{array}$ & $\begin{array}{c}6 \cdot 0^{\star} \\
(0.3 \text { to } 11 \cdot 7)\end{array}$ & $\begin{array}{c}24 \cdot 6 \star \star \star \\
(18 \cdot 7 \text { to } 30 \cdot 5)\end{array}$ & $0.66 t$ \\
\hline
\end{tabular}

${ }^{\star} \mathrm{p}<0.05,{ }^{\star \star} \mathrm{p}<0.01,{ }^{\star \star \star} \mathrm{p}<0.001$ ( $\mathrm{z}$ test). ${ }^{3} \quad \mathrm{tp}<0.01$ for difference between medians (Mann-Whitney rank sum test). 